\title{
Genomic insights into the recent population history of Mapuche Native Americans.
}

\author{
Lucas Vicuña $^{\dagger, \ddagger}$, Anastasia Mikhailova ${ }^{\S}$, Tomás Norambuena ${ }^{\dagger, \ddagger}$, \\ Anna Ilina ${ }^{\S}$, Olga Klimenkova ${ }^{\S}$, Vladimir Shchur*§, and Susana \\ Eyheramendy*†, \\ †Faculty of Engineering and Sciences, Universidad Adolfo Ibáñez, \\ Peñalolén, Santiago, Chile \\ ${ }_{\ddagger}^{\ddagger}$ Instituto Milenio de Investigación Sobre los Fundamentos de los \\ Datos (IMFD), Santiago, Chile \\ $\S$ International Laboratory of Statistical and Computational \\ Genomics, HSE University, Russian Federation
}

\begin{abstract}
The last few years have witnessed an explosive generation of genomic data from ancient and modern Native American populations. These data shed light on key demographic shifts that occurred in geographically diverse territories of South America, such as the Andean highlands, Southern Patagonia and the Amazon basin. We used genomic data to study the recent population history of the Mapuche, who are the major Native population from the Southern Cone (Chile and Argentina). We found evidence of specific shared genetic ancestry between the Mapuche and ancient populations from Southern Patagonia, Central Chile and the Argentine Pampas. Despite previous evidence of cultural influence of Inca and Tiwanaku polities over the Mapuche, we did not find evidence of specific shared ancestry between them, nor with Amazonian groups. We estimated the effective population size dynamics of the Mapuche ancestral population during the last millennia, identifying a population bottleneck around $1650 \mathrm{AD}$, coinciding with a period of Spaniards' invasions into the territory inhabited by the Mapuche. Finally, we show that admixed Chileans underwent post-admixture adaptation in their Mapuche subancestry component in genes related with lipid metabolism, suggesting adaptation to scarce food availability.
\end{abstract}

Keywords: Mapuche, Native Americans, genetic history, adaptation

\footnotetext{
*Corresponding authors: S.E. (email: susana.eyheramendy@uai.cl) \& V.S. (email: vshchur@hse.ru)
} 


\section{Introduction}

Human presence in the American Continent dates back to at least 21000 years before present (BP), as confirmed by recent findings in North America [1, 2, 3. According to the current understanding derived from archaeogenetics, the first Native American ancestral population diverged from East Asians, crossed Beringia $25000-23000 \mathrm{BP}$ and shortly split into two lineages $17000-14600 \mathrm{BP}$, called Ancestral-A (or Southern Native American) and Ancestral-B (or Northern Native American). While Ancestral-B originated eastern North American populations, Ancestral-A originated the lineage of the 12900-12700 BP Anzick1 individual associated with the Clovis Culture and rapidly radiated to Central and South America [4, 5, 6].

The peopling of South America began at least 14000 before present (BP), as revealed by the archaeological site of Monte Verde in Southern Chile [7]. Around 3000 years later, an ancient lineage that split from Ancestral-A appears in Central Chile. This lineage is represented by an individual from Los Rieles (Chile_LosRieles_10900BP) 6] 8], has high genetic affinity with the Anzick-1 Clovis individual, and was almost completely replaced between $10900-9000$ BP by a second Ancestral-A branch population. This latter lineage explains the genetic diversity of most present-day Native populations from Central and South America, with two exceptions: i) Central Andeans, who share an Ancestral-A-derived lineage related to $4900 \mathrm{BP}$ individuals from the California Channel Islands (USA_SanNicolas_4900BP) [] ; and ii) some populations from the Amazon basin and the northwestern Coast of South America, who have a minor Australasian component 9, 10. Around $5100 \mathrm{BP}$ and 700 $\mathrm{BP}$, there is evidence of high genetic affinity between individuals from Los Rieles (Chile_LosRieles_5100BP) and Conchali (Chile_Conchali_700BP), respectively, with modern Huilliche and Pehuenche [8], two Mapuche subpopulations from the Araucanía Region of southern Chile (Figure 1).

The Mapuche (who self-denominated Reche at the time of contact with Europeans) are a Mapudungún-speaking Native group from Chile and Argentina, and the only extant Native population living in Central-Southern Chile. Based on their geographic location, the Mapuche have in general been divided in three main groups: Picunche (northern lowlands), Huilliche (southern lowlands) and Pehuenche (southeastern foothills of the Andes) [11. The population history of the Mapuche has been debated. An hypothesis posited by historian Francisco Antonio Encina and taught in many Chilean schools today is that they arrived to the Araucanía Region from the Argentinian Pampas, crossing the Andes Mountains one or two centuries before the Inca invasions that took place between 1471 and $1532 \mathrm{AD}$ [12] [13]; see also [14]). A more accepted hypothesis is that groups of hunter-gatherers lived in the Araucanía since ancient times and that one them imposed their culture over the others at least $1500-1400 \mathrm{BP}$ [15. Indeed, the Mapuche might be direct descendants of the pre-Columbian archaeological cultures Pitrén (100 - 1100 AD) and El Vergel (1100-1450 AD) of Araucanía [13. The Picunche, who were part of the Aconcagua Culture (900 - $1450 \mathrm{AD})$, were conquered by the Inca Empire during their expansion to 
present-day North/Central Chile in 1438-1539 AD, as revealed by hundreds of Inca archaeological sites [13] and by historical records [15]. However, it is unknown whether these two populations underwent genetic admixture. Further, it is not clear whether southern Mapuche, namely, Huilliche and Pehuenche, were culturally or genetically influenced by the Inca [13].

It has also been suggested that the Mapuche had pre-Columbian cultural exchange with the Tiwanaku Culture $(\sim 600-1100 \mathrm{AD})$ from the Central Andes as well as with Amazonian groups. Dillehay et al., 2007 [16] hypothesized that the Mapuche society underwent a series of cultural changes following the collapse of the Tiwanaku empire on $\sim 1100-1300 \mathrm{AD}$, causing a southward migration wave that would have reached the Araucanía Region. Similarly, the authors hypothesized that ancient populations from Araucanía may have been culturally influenced by groups from the southern Amazon basin. Both cultures have similar ceramic traditions with apparent roots in central Chilean or northwest Argentine cultures [16]. Despite these observations, it is not known whether the Mapuche share specific genetic ancestry with Andean or Amazonian groups.

During the $15^{\text {th }}$ and $16^{\text {th }}$ centuries, the Mapuche resisted the invasions of the Inca Empire [17] and the Spanish Kingdom [18]. The arrival of Spaniards brought along infectious diseases that caused severe epidemics among the Mapuche, such as typhoid fever (1558 AD) and smallpox (1563 AD) [15]. Arguably, wars and diseases resulted in many deaths among the Mapuche 15. The arrival of Spaniards also resulted in their admixture with the Mapuche, originating modern Chileans centuries later. Possibly, Chileans inherited adaptation signals from their Native American ancestors, to cope with selective pressures such as infectious diseases, food scarcity and extreme climates, similar to other populations with Native American ancestry [19, 20, 21, 22, 23, 24, 25].

The present study had three aims: i) Looking for specific shared ancestry between the Mapuche and populations from the Southern Cone, the Central Andes and the Amazon Basin; ii) Estimating the effective population size $\left(\mathrm{N}_{e}\right)$ trajectory of the Mapuche lineage during the last millennia; and iii) Detecting Mapuche-specific signatures of natural selection inherited by modern admixed Chileans.

\section{Results}

Here we present several results which put together the whole picture of the Mapuche specific history. We identified specific shared ancestry events between the Mapuche and ancient populations from the Southern Cone. We confirmed that the Mapuche trace most of their ancestry from a lineage present in Central Chile at least $700 \mathrm{BP}$ [8] (Aconcagua Culture [13]), and probably before 5100 BP. We also identified events of gene flow with Southern Patagonian groups. Despite previous observations of cultural exchange between important Andean polities with the Mapuche (such as Inca and Tiwanaku) [16, 13, we did not find genetic exchange between them, nor with Amazonian groups. Our analysis demonstrates that there is an agreement between the Mapuche effective popu- 
bioRxiv preprint doi: https://doi.org/10.1101/2021.11.25.470066; this version posted November 29, 2021. The copyright holder for this preprint (which was not certified by peer review) is the author/funder, who has granted bioRxiv a license to display the preprint in perpetuity. It is made available under aCC-BY-ND 4.0 International license.

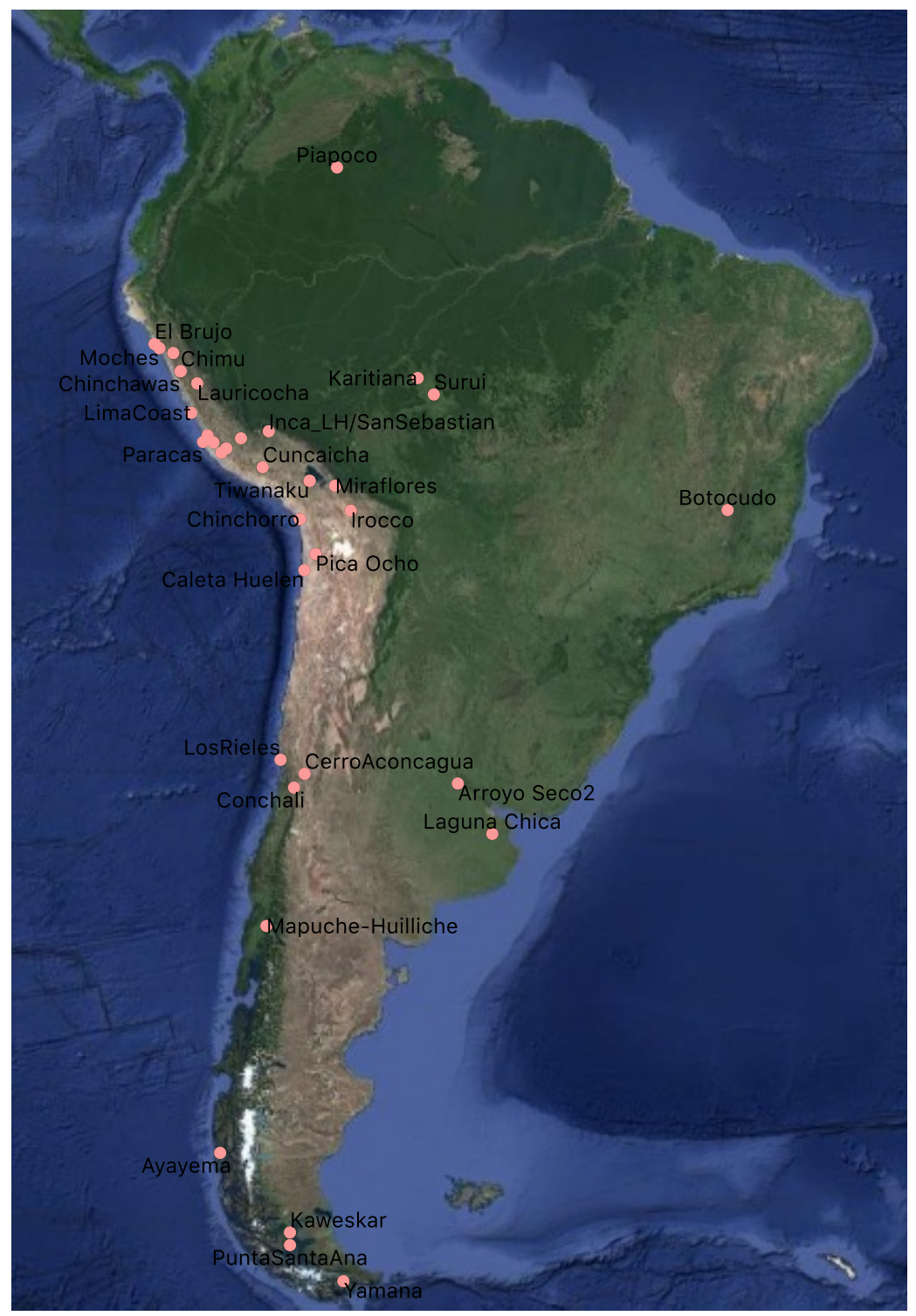

Figure 1. The geographic location of populations used in this study. Shown is the location of representative populations or archaeological sites from the Southern Cone, the Central Andes and the Amazon Basin. Some archaeological sites harbor $\geq 1$ populations. (e.g., LosRieles harbors Chile_LosRieles_5100BP and Chile_LosRieles_10900BP). To avoid overfilling the map with text, we show only some populations (Figure 2). This map was done with GGI3.10 (https://www.qgis.org/en/site/) 
lation size decline inferred from genetic data and a period of diseases and wars caused by foreign invasions into Mapuche territory between the $15^{\text {th }}$ and $17^{\text {th }}$ centuries [15, 17. Finally, we were able to capture Mapuche-specific adaptation signals inherited by admixed Chileans. These results provide a comprehensive insight in the history of the Mapuche population, which is the major Native American population in Chile and Argentina.

\subsection{Evidence of specific shared ancestry between the Ma- puche and ancient populations from the Southern Cone}

We estimated genetic affinity between the Mapuche and Native South American populations from distinct geographical regions. For this, we used a set of 124, 470 variants that fulfilled two conditions: i) They have $<0.01$ non-Native American local ancestry mean in our sample of 11 Mapuche-Huilliche individuals; and ii) They intersect between the Mapuche-Huilliche dataset and the 1240K_HO dataset of the Allen Ancient DNA Resource (AADR) [26] (see Methods for details).

We first analyzed whether ancient populations from the Southern Cone region of South America were ancestors of the Mapuche (Southern Cone was broadly defined as the regions from Chile and Argentina located at the same or lower latitudes than the archaeological site of Los Rieles, see Figure 1). We used 11 individuals belonging to the Huilliche branch of the Mapuche (MapucheHuilliche). We computed D(Mbuti, Ancient Southern Cone; Modern South America, Mapuche) statistic, iterating over different combinations of Ancient Southern Cone and Modern South American populations. Modern was defined as $\leq 100 \mathrm{BP}$. We found consistent evidence of allele sharing between Chile_Conchali_700BP (700 - 900 year-old individuals from Central Chile) and the Mapuche-Huilliche, as revealed by Z-scores $>3$, in 7 independent significant tests (Supplementary File 1A and Figure 2A), confirming previous findings [8]. We also found evidence of allele sharing between Mapuche-Huilliche and Chile_LosRieles_5100BP (2 significant tests), Argentina_ArroyoSeco2_7r00BP (1 significant test), Chile_WesternArchipelago_Kaweskar_1200BP (1 significant test), and Chile_Yamana_BeagleChannel_800BP (2 significant tests), relative to modern Andean and/or Amazonian populations (Figure 2A).

Supplementary File 1A shows the tested populations and the corresponding Z-scores. We evaluated whether close genetic relatedness between MapucheHuilliche individuals could affect the D-statistic results. Thus, we performed the same tests described before but keeping Mapuche-Huilliche individuals without relatedness of first and second degree, obtaining a set of 6 individuals. The results were almost identical (data not shown). Figure 1 shows the geographic location of populations from representative regions used in this study.

We used qpGraph 27] to model the phylogenetic relations between the Mapuche-Hulliche and other ancient as well as modern Southern Cone populations. Based on our D-statistic results and on previous results [8] [6] 28, we started our phylogenetic tree including the Anzick1 Clovis individual ( $U S A_{-} A n z-$ _ra_SG), Argentina_ArroyoSeco2_r700BP, Chile_LosRieles_5100BP and Chile- 
A

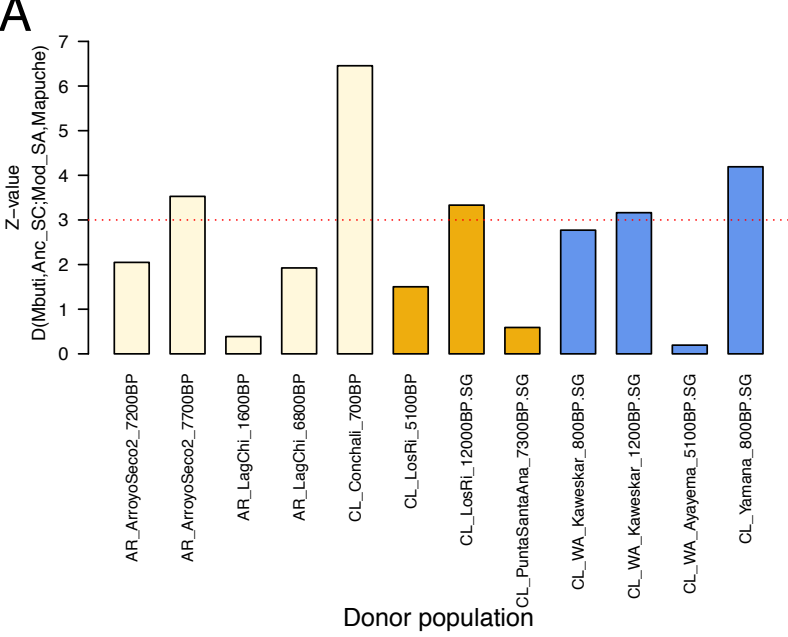

$\mathrm{C}$

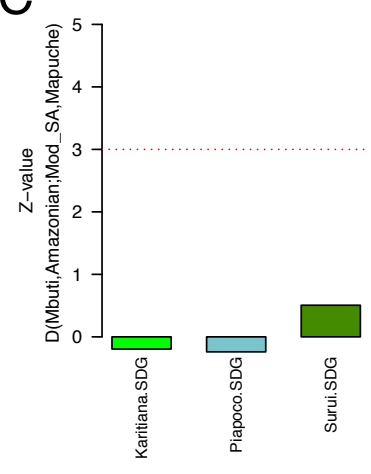

$\mathrm{B}$

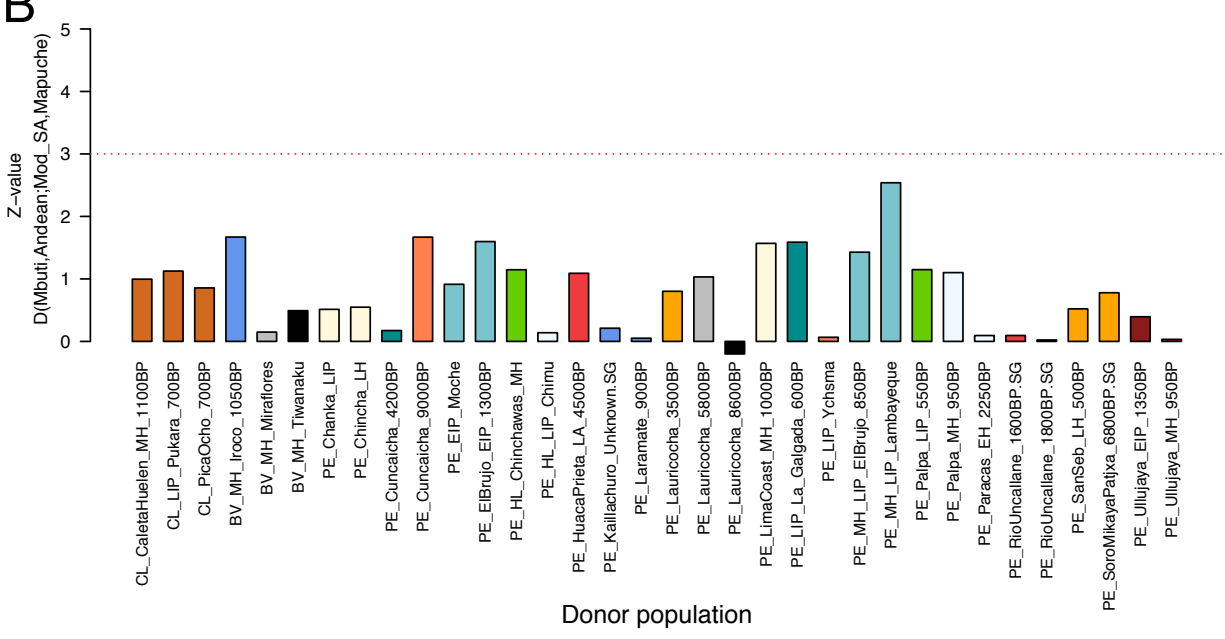

Figure 2. Genetic affinity between Mapuche-Huilliche and Southern Native American populations. Distribution of Z-values (y-axis) for Dstatistic tests between a donor population and the Mapuche-Huilliche. A. The donor population is Ancient Southern Cone (Anc_SC). B. The donor population is Central Andean. C. The donor population is Amazonian. The red dotted horizontal line represents the significance threshold of $\mathrm{Z}=3$. For results of the same population but different sequencing technologies (e.g., Karitiana.DG vs. Katitiana.SG [26]), the figure shows the worst Z-value. For each donor population/Mapuche-Huilliche pair, the figure shows the result with the highest Z-value. All remaining test results are found in Supplementary File 1A-C. With a few exceptions, the figure shows tests with $Z>0$. Due to space limits, we show short versions of the original populations' names. Conversions between the original (long) names and short names are found in Supplementary File 1D. 
_Conchali_700BP. We used Mbuti as outgroup and included Aymara as a representative modern descendant of the California Channel Islands-related Native American branch population. Later, we included ancient populations from Southern Patagonia. We obtained a model tree by fitting the Mapuche-Huilliche as a mixture of a lineage from Central Chile (related to Chile_Conchali_700BP; $97 \%)$ and an ancient lineage from Southern Patagonia (3\%; related to Chile_WesternArchipelago_Kaweskar_1200BP.SG) (Figure 3).

\subsection{No evidence of specific shared ancestry between the Mapuche with Central Andean or Amazonian popu- lations}

We tested for specific shared ancestry between the Mapuche-Huilliche and Central Andean populations, such as Inca and Tiwanaku. We included Inca individuals from different locations as well as Tiwanaku individuals from time periods covering the whole Tiwanaku civilization (see Discussion) [28]. We computed D(Mbuti, Ancient Central Andean; Modern South America, Mapuche) statistic, by iterating over all combinations of ancient Central Andean populations (Figure 2B) and modern South American populations. We did not find evidence of specific shared ancestry among these groups (Figure 2B). Supplementary File 1B shows the tested populations and the corresponding Z-scores.

We modeled the phylogenetic relations between the Mapuche-Huilliche and Central Andean populations, similarly as before. We included Tiwanaku (Bolivia_MH_Tiwanaku), Inca individuals (Peru_SanSebastian_LH_500BP and Peru_LH_Inca), as well as an older individual from a nearby archaeological site $($ Peru_Laramate_900BP). We obtained a model fitting the Mapuche-Huilliche as a mixture of Chile_Conchali_700BP (66\%) and an undefined Native American branch (34\%) (Figure 4).

Our D-statistic results also show that there is specific shared ancestry between modern Amazonian and ancient Central Andean populations relative to the Mapuche, as revealed by Z-scores $<-3$ (e.g., Karitiana vs. Peru_Chincha_LH, Peru_Ullujaya_MH_950BP, Peru_LimaCoast_MH_1000BP and Peru_MH_LIP_Lambayeque) (Supplementary File 1B)

We tested for genetic affinity between the Mapuche-Huilliche and the following modern populations from the Amazon Basin (hereafter referred as "Amazonian") for which there is public genomic data: Surui, Piapoco and Karitiana. We computed D(Mbuti, Amazonian; Modern South America; Mapuche) statistic, iterating over modern Amazonian and modern South American populations. We did not find evidence of significant allele sharing between Amazonian groups and the Mapuche-Huilliche (Figure 2C and Supplementary File 1C).

\subsection{Mapuche effective population size}

We used single nucleotide polymorphism (SNP) data from modern admixed Chileans [29] to estimate how the effective population size $\mathrm{N}_{\mathrm{e}}$ of Mapuche's 


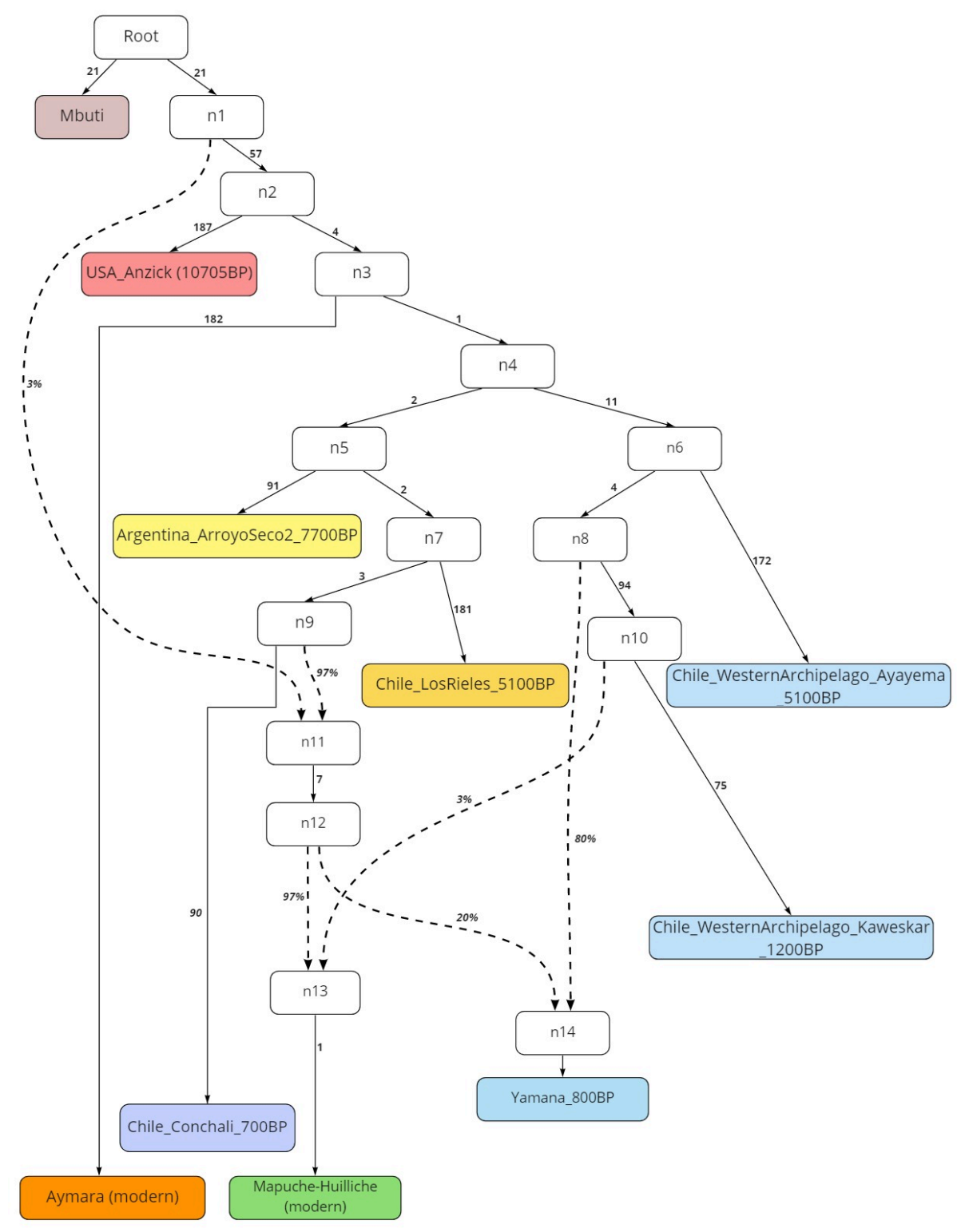

Figure 3. Admixture graph relating the Mapuche-Huilliche with ancient Southern Cone populations. Numbers along branches represent units of shared genetic drift. Nodes labeled with $\mathrm{n} 1$, n2, etc., represent unknown populations necessary to fit the model. Percentages indicate admixture proportions. Z-score of the worst $f 4$ (Anzick1, Aymara, Argentina_ArroyoSeco_7700BP, Chile_Conchali_700BP) is 2.585.. This graph was made with Miro (https://miro.com/) 


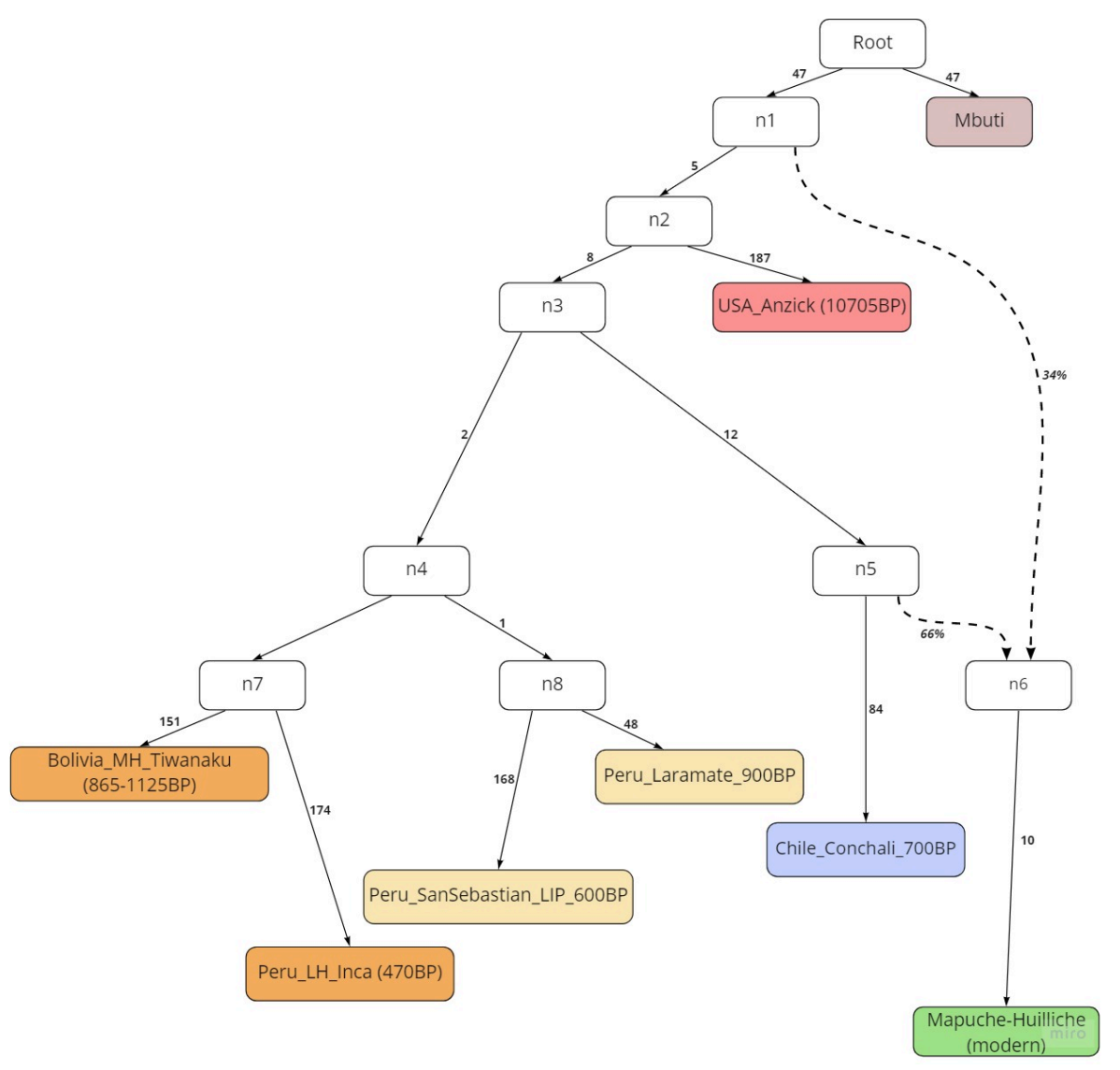

Figure 4. Phylogenetic tree relating the Mapuche-Huilliche with ancient Central Andean populations. Numbers along branches represent units of shared genetic drift. Nodes labeled with n1, n2, etc., represent unknown populations necessary to fit the model. Percentages indicate admixture proportions. Z Z-score of the worst $f 4($ Peru_LH_Inca, Peru_Laramate_900BP, Chile_Conchali_700BP, Peru_SanSebastian_LIP_600BP) is 2.166.. This graph was made with Miro (https://miro.com/) 
lineage changed over the last millennia. We implemented a methodological approach based on the relative length of Identity-by-descent (IBD) segments of specific ancestries, which is suitable for SNP array data 30. Specifically, the Chilean individuals used in our study have on average 0.438 Mapuche Native American, 0.026 Aymara Native American, 0.521 European and 0.015 African mean global ancestry proportions [31]. In order to analyze $\mathrm{N}_{\mathrm{e}}$ changes that are specific to the Mapuche, we excluded 592 admixed individuals with $\geq 0.01$ global Aymara ancestry, obtaining a final dataset of 312 individuals. Based on segments of at least 2 centiMorgan genetic length, this method is able to accurately estimate $\mathrm{N}_{\mathrm{e}}$ within the last hundreds of generations. Briefly, we used the refinedIBD program [32] to detect such segments, RFMix 33] to estimate the (local) Native American ancestry of each SNP (haplotype) and IBDNe [34] to estimate ancestry-specific $\mathrm{N}_{\mathrm{e}}$. We observed that the Mapuche ancestral component underwent a population bottleneck that reached a minimum of $\mathrm{N}_{\mathrm{e}}=$ 10,300 at 13 generations ago (year $\sim 1650 \mathrm{AD}$ ) compared to $\mathrm{N}_{\mathrm{e}}=27,200$ at 29 generations ago (year $\sim 1208 \mathrm{AD}$ ). Since the bottleneck, the $\mathrm{N}_{\mathrm{e}}$ showed a steady increase until the present time (Figure 5).

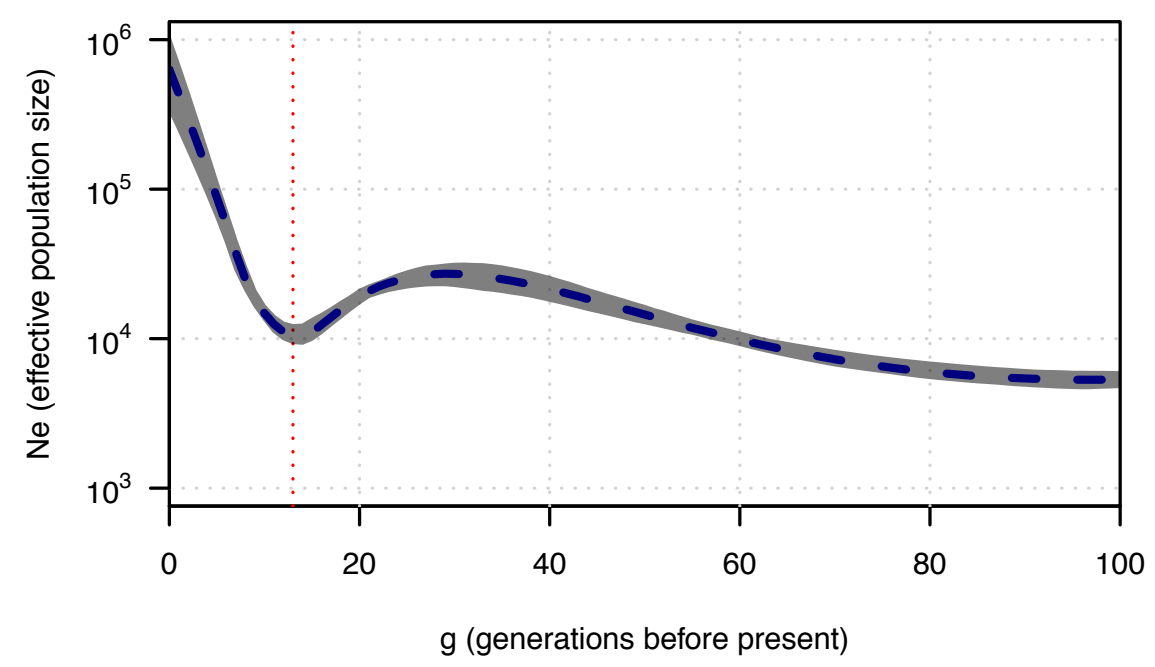

Figure 5. Temporal trajectory of Mapuche-specific $\mathbf{N}_{\mathrm{e}} \cdot \mathrm{N}_{\mathrm{e}}$ trajectory (shown on log-scale) as a function of generations (g) before present. The dotted vertical line represents the recent $(\leq 50 \mathrm{~g})$ minimum $\mathrm{N}_{\mathrm{e}}$ in the Mapuche ancestral component, corresponding to 13 generations ago. The grey area represents the $95 \%$ bootstrap confidence intervals. The plot is based on the analysis of 312 admixed individuals with Mapuche, European and African ancestries. 


\subsection{Post-admixture selection in the Mapuche component of admixed Chileans}

In order to identify genomic regions enriched in Mapuche ancestry but not Aymara ancestry, we implemented the following strategy. 1) We performed $T$-tests to detect extreme deviations in the Native American local ancestry proportion over the genome-wide Native American mean in the full set of 904 admixed individuals. We identified 2, 247 variants crossing the genome-wide threshold of $P<10^{-5}$ recommended for recently-admixed populations [35. 2) To minimize potential confounding effects produced by Aymara ancestry, we only considered the 312 individuals with $\leq 0.01$ Aymara Native American ancestry. 3) We performed the same $T$-tests on the subset of 312 individuals, identifying 467 variants with $P<10^{-5}$. 4) To avoid a possible ascertainment bias introduced by selecting only individuals with Mapuche ancestry, we intersected the SNPs with significant deviations in the set of 904 individuals and in the set of 312 individuals. This resulted in a total of 65 SNPs. All of these SNPs achieved an association $P$-value of $P=2.4 \times 10^{-6}$ and they are located within five genes mapping close together on chromosome 16, namely, CPNE2, FAM192A, RSPRY1, PLLP and ARL2BP. Figure 6 shows genome-wide deviations in Native American ancestry in the subset of 312 individuals enriched with Mapuche ancestry, highlighting genes associated with the 65 significant variants that intersected between the two sets of individuals. Supplementary Table 1 shows the 65 SNPs and their variant annotations.

In order to rule out that these significant deviations were caused by genetic drift, we performed neutral simulations of local ancestry (see Methods for details). We set a single admixture event between Native Americans, Europeans and Africans in proportions 0.46, 0.52 and 0.015, respectively, mimicking the real data. Admixture occurred 10 generations ago, which was the time where the main pulse of admixture occurred in admixed Chileans [36]. The effective population size of admixed Chileans was set to $\left(\mathrm{N}_{\mathrm{e}}\right)=6,000$, based on previous estimates [37. We simulated sample sizes of $N=156,312,624$ and 904. For each $N$, we calculated $T$-test $P$-values for the SNP with a maximal deviation in Mapuche ancestry, obtaining $P=0.00877,0.00103,0.00214,0.00006$ for $N=156,312,624,904$ respectively. Thus, no simulated SNP achieved the significance threshold of $P<10^{-5}$ recommended for this test in recently admixed populations [35], ruling out that the significant deviations observed in the real SNPs were caused by drift.

\section{Discussion}

In this study, we tested hypotheses of specific shared ancestry between the Mapuche-Huilliche from Southern Chile and geographically distant populations from Native South America (Figure 1). We found consistent evidence of significant allele sharing between the Mapuche-Huilliche and lineages represented by Chile_Conchali_700BP and Chile_LosRieles_5100BP in Central Chile, confirm- 


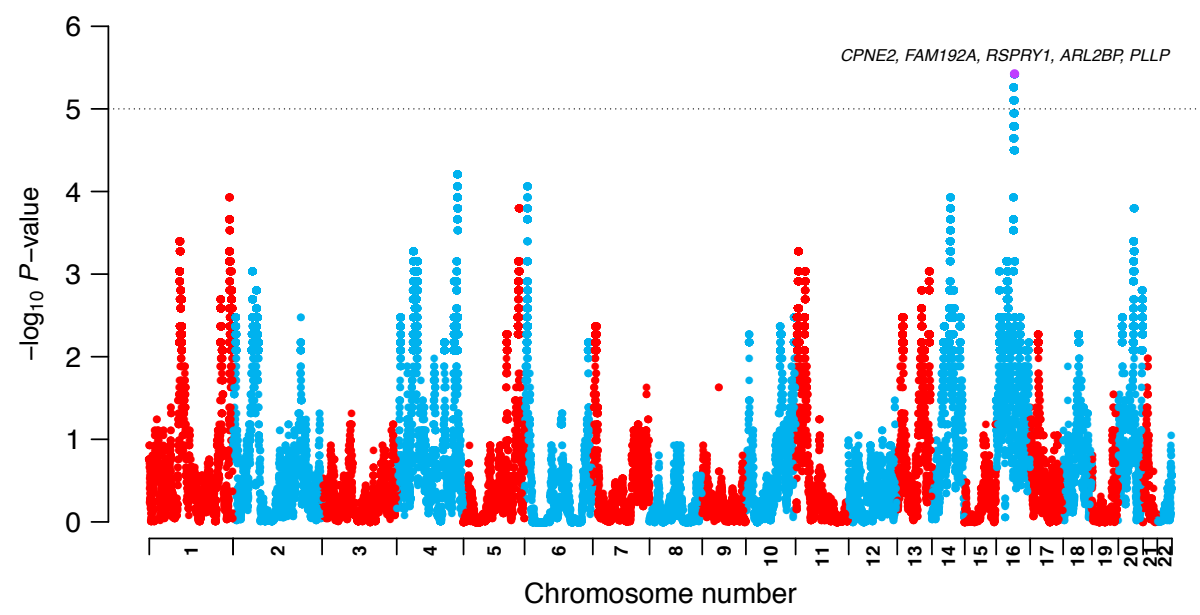

Figure 6. Genome wide deviations in Mapuche ancestry among Chileans. Deviations in Native American local ancestry over the genome-wide Native American local ancestry mean, expressed as the $-\log _{10}$ ( $T$-test $P$-value) of deviations. The dotted horizontal line represents the cutoff threshold of $P<10^{-5}$ for deviations considered significant [35]. Highlighted in violet are genes associated both with selected variants in the set of 312 individuals as well as in the 904 individuals. 
ing previous findings [8]. Chile_Conchali_700BP contributed most of MapucheHuilliche's ancestry. This is in agreement with anthropological evidence showing a cultural influence from groups of Central Chile over groups of Araucanía. For instance, there are clear similarities in the pottery style (e.g., asimetric crocks called jarros pato in Spanish) between the Llolleo Culture (1800 - 1200 BP) of Central Chile and the Mapuche as well as the Pitrén Culture of Southern Chile $(100-1100$ AD) [13]. We also found significant allele sharing between the Mapuche-Huilliche and a lineage represented by individuals of $\mathrm{Ar}$ gentina_ArroyoSeco2_7700BP found in a site close to the northwestern Atlantic Coast of Argentina (Figure 1). Further, we found significant allele sharing between the Mapuche-Huilliche and populations from Southern Patagonia, namely, Chile_WesternArchipelago_Kaweskar_1200BP and Chile_Yamana_BeagleChannel$\_800 B P$. Together, these observations support the hypothesis that the MapucheHuilliche are mainly the descendants of a lineage present in Central Chile at least $700 \mathrm{BP}$, and probably before $5100 \mathrm{BP}$, with some gene flow from Southern Patagonian lineages.

It is well known that the Inca Empire (or Tawantisuyo in Quechua language) (1438-1539 AD) occupied a big fraction of present-day Central Chile. This region was included in the so-called Collasuyo Region of the Empire and was populated by the Mapuche-Picunche. This region harbors hundreds of Inca archaeological sites [13, including pukara (fortresses), cemeteries, agricultural and hydraulic complexes, roads, among others. Many of such sites contain Inca cultural objects of personal use, such as pottery, clothes, quipu (textile system for counting), knives, pichcas (miniature games) and others [13], indicating a clear influence over local cultures. Different kinds of evidence indicate an influence of the Inca over the Picunche. The latter coexisted with the Inca at the time of Europeans' arrival [15]. Also, the center of Chile's capital city Santiago, which lies within former Picunche territory, was once an Inca settlement [38. The presence and cultural influence of the Inca in the Araucanía Region, where the Mapuche-Huilliche lived, is more contentious, in part due to the preservation of a few distinct cultural objects. For instance, the pottery style of local cultures contemporary to the Inca, such as El Vergel, does not indicate a clear Inca influence [13] (but see [39]). We did not find evidence of significant allele sharing between the Mapuche-Huilliche and the Inca, represented by a Peru_LH_Inca individual from 470 BP found close to Ayacucho, Perú, and by 500 BP individuals from San Sebastián, close to Cuzco, Perú [28. One explanation would be that the Mapuche-Huilliche did not admix with the Inca. Another possibility is that the ancestors of the 11 Mapuche-Huilliche individuals used in this study lived in relative isolation until present, since they inhabit the Huapi Island, located in the Ranco Lake 40. We also did not find significant genetic affinity between the Mapuche-Huilliche and the lineage of an Inca boy found in the Aconcagua Mountain [5] (Supplementary File 1A), which is located at the eastern border of former Picunche's territory. It is likely that this Inca boy was brought from the Central Coast of Peru [41] [5] and thus does not represent an Inca-like lineage. Of note, the Aconcagua Mountain is located $\sim 100 \mathrm{~km}$ away from the Conchalí archaeological site in Central Chile (Chile_Conchali_700BP) 
(Figure 1), which was also Picunche's territory, but the Chile_Conchali_700BP lineage does have high genetic affinity with the Inca boy [28].

A previous study hypothesized that the Mapuche had cultural exchange with the Tiwanaku [16, a powerful preincaic empire that flourished from around 600 to $1100 \mathrm{AD}$ around the Titicaca Lake in present-day Bolivia and Perú [42]. For reasons not completely understood, the Tiwanaku Empire collapsed by $\sim 1100-1300 \mathrm{AD}$, possibly leading to groups migrating southwards towards Central/South Chile [16]. Raised fields dated $\sim 1000 \mathrm{AD}$ were found in the Araucanía Region where the Mapuche-Huilliche lived [16]. These fields have similar technological and typological features as those found $3500-2500 \mathrm{~km}$ to the north along the Peruvian Coast, at the lowlands of Northeast Bolivia and at the Lake Titicaca Basin of Northwest Bolivia [16. The sudden appearance of such fields after AD 1000 suggests that they might have been introduced by the Tiwanaku [16]. Despite these observations, we did not find evidence of specific shared ancestry between the Mapuche-Huilliche and individuals from different time periods of the Tiwanaku Empire (1125BP, 990BP, 900BP and 865BP [28 [26]). Neither did we find evidence of shared ancestry with other Central Andean populations. However, it is possible the there was a direct or indirect cultural influence of some tested Central Andean populations over the Mapuche-Huilliche, but without gene flow.

Dillehay et al., 2007 [16] also hypothesized that a cultural exchange occurred between Mapuche and Amazonian groups. This is based on similar ceramic traditions, funeral practices 43, 44, shared genetic markers and linguistic similarities between Mapudungún and languages spoken by southern Amazonian groups such as Arawak, Tacanan and Guarani [16] [13]. However, we did not find evidence of specific shared ancestry between Amazonian populations and the Mapuche-Huilliche. Nevertheless, we cannot completely rule out shared ancestry, since we included a subset of three Amazonian populations. Future research will be needed to test for genetic affinity with other Amazonian groups.

Our results show that the Mapuche's $\mathrm{N}_{e}$ exhibited a steady decline starting 30 generations ago, and reaching a minimum at 13 generations ago (year 1650 $\mathrm{AD}$ ). This timing is relatively similar to a previous study's estimate that modeled an abrupt population bottleneck for the Mapuche-Huilliche at $\sim 325$ BP (year $\sim 1700 \mathrm{AD}$ ) using imputed SNP array data 22. We estimated a gradual and milder decrease in Mapuche's $\mathrm{N}_{e}$ from $\mathrm{N}_{e} \sim 27,200$ (29 generation ago) to $\mathrm{N}_{e} \sim 10,300$ (13 generations ago). This decrease was $62.1 \%$, thus milder than the $94 \%$ reduction estimated in the aforementioned study. The decline in Mapuche's $\mathrm{N}_{e}$ is similar in magnitude as that underwent by the Native American component of Ecuatorians and Nicaraguans, lower to that exhibited by Mexicans [30] and higher than Native Americans from Brazil [45]. One possible cause of the decline in the Mapuche's population size is war. Between 1485 and $1493 \mathrm{AD}$, the Mapuche-Picunche fought the Battle of the Maule against the Inca in response to the southward expansion of this empire into present Central Chile (unknown date between 1471 and 1532 AD) [17, 46]. It is likely that this battle resulted in many casualties among the Mapuche-Picunche, while the Huilliche and the Pehuenche would have been mostly unaffected due to their dis- 
tant location. Later on, the Mapuche resisted the Spaniards' invasions between 1546 - 1662 AD during the long Arauco War fought in the Araucanía Region, which ended with the victory of the Mapuche [18]. The number of deaths among the Mapuche is unknown. A second cause of Mapuche's population decline were epidemics spread by Europeans. According to historical estimates, epidemics of typhoid fever (1558 AD) and smallpox (1563 AD) would have killed $30 \%$ and $10 \%$ of the total population of 1,000,000 individuals, respectively. The most affected group would have been the Picunche, who had more contact with Spaniards [15].

Our ancestry enrichment test detected significant deviations in the local Mapuche ancestry proportion in the genes CPNE2, FAM192A, RSPRY1, PLLP and $A R L 2 B P$. Interestingly, most of these genes have been associated with lipidrelated traits in genome-wide association (GWA) studies. CPNE2 variants are associated with high density lipoprotein (HDL) cholesterol levels $\left(P=5 \times 10^{-12}\right)$ [47. RSPRY1 variants are associated with HDL cholesterol levels $(P=4 \mathrm{x}$ $\left.10^{-42}\right)$ and Apolipoprotein A1 levels $\left(P=3 \times 10^{-30}\right)$ [47. PLLP variants are associated with HDL cholesterol levels $\left(P=6 \times 10^{-12}\right)$ [48. In addition, $P L L P$ variants associated with traits related to red blood cells, such as mean corpuscular hemoglobin concentration $\left(P=2 \times 10^{-12}\right)$, hematocrit $(P=2 \mathrm{x}$ $\left.10^{-14}\right)$, hemoglobin concentration $\left(P=1 \times 10^{-11}\right)$ and red blood cell count $(P=$ $1 \times 10^{-12}$ ) [49. FAM192A and ARL2BP have not been GWAS-associated to any trait. Extreme deviations of local Mapuche ancestry in genes involved in lipid metabolism might be due to post-admixture selection in response to scarse food availability among the first admixed Chileans. This may have resulted in modern Chileans tending to accumulate more fat in their body in a time where food scarcity is not a problem (see "thrifty hypothesis" [50]). Indeed, present-day Mapuche and admixed Chileans have a high incidence of lipid-related disorders such as insulin resistance, obesity, cholesterol gallstones and metabolic syndrome [51, 52].

In summary, our results provide new insights into the recent population history of the Mapuche as well as adaptations underwent by them, adding more pieces to the puzzle of Native American's genetic history.

\section{Subjects and Methods}

\subsection{Samples}

We used genomic data from 11 Mapuche-Huilliche individuals [40. We used SNP array data from 904 admixed Chilean individuals [31] from the "Growth and Obesity Chilean Cohort Study" (GOCS) [29. We obtained curated genomic data of ancient and modern Native American populations from the Allen Ancient DNA Resource (1240K_HO dataset V44.3), typed at 597, 573 sites [26]. Supplementary Table 1D lists the populations used in this study, which have been previously published [53, 54, 4, 55, 56, 6, 55, 22, 57, 58, 59]. 


\subsection{Local Ancestry Estimation}

We used RFMix 33 to infer the local ancestry of haplotypes in the MapucheHuilliche and in the admixed Chilean individuals. We used populations from the 1000 Genomes Project 60] as references for Native Americans, Europeans and Africans. As source for Native American ancestry we used Peruvians (PEL) with $>95 \%$ Native American ancestry $(n=29)$. For African ancestry we used Yoruba in Ibadan, Nigeria (YRI, n=108). For European ancestry we used Iberian populations in Spain (IBS, $\mathrm{n}=107$ ), which best resemble the Spaniard ancestral component of populations from modern Chile [61]. RFMix requires phased haplotypes, which were inferred with Beagle v.5 [62], using the HapMap37 human genome build 37 recombination map. We ran RFMix using the following parameters recommended in the manual: PopPhased $-\mathrm{n} 2-\mathrm{w} 0.2--\mathrm{fb} 1$. We inferred local ancestry at 4,596, 314 variants among the Mapuche-Huilliche.

\subsection{Global Ancestry Estimation}

Global ancestry proportions of Mapuche-Huilliche and admixed Chileans were estimated with Admixture 1.3 [63, similarly as described previously 31. For the African and European ancestry, we used the same reference populations mentioned in the previous section. For the Native American ancestry, we used the 11 Mapuche-Huilliche individuals [40, 64 Aymara individuals 64, 22] and the 29 Peruvian (PEL) individuals with > 95\% Native American ancestry.

\subsection{Deviations of local ancestry}

The mean local ancestry at each SNP was estimated using a published R script [37. The Native American proportion at each SNP was compared with the Native American genome-wide mean using one-tailed $T$-tests, as described previously [37. Variants achieving a significance threshold of $P<10^{-5}$ were considered to be under post-admixture selection [35].

\subsection{Identification of unadmixed Native American haplo- types}

The Mapuche-Huilliche individuals from our dataset have $4-8 \%$ non-Native American global ancestry proportions, mainly of European origin [40]. In order to obtain unadmixed Native genomic segments, we excluded variants showing $>0.01$ mean European or African local ancestries, obtaining 1,958, 132 variants. Among them, we obtained a total of 124,470 variants that intersected between the Mapuche and 1240K_HO datasets. We used KING software [65] to detect and exclude five individuals with second degree relatedness, namely, GS000011194-ASM, GS000011195-ASM, GS000011196-ASM, GS000011201-ASM and GS000012210-ASM). 


\subsection{D-statistics}

Before computing D-statistics with ADMIXTOOLS [27, we solved some problems of format conversions related to the convertf program. When converting from EIGENSTRAT to Plink binary, the resulting fam file had ID numbers in column 1 and population labels in column 6 (e.g. 13199 Mapuche:GS000011196ASM 002 Mapuche). Because the Plink fam format requires the Family ID (i.e. population ID) to be in the first column, columns 1 and 6 in the $\mathrm{fam}$ file were switched. Using Plink 1.9, 124, 470 SNPs intersecting between the Mapuche and 1240K_HO datasets were extracted. The 1240K_HO dataset had individuals with long IDs that killed the convertf process when converting from Plink binary to EIGENSTRAT format. Thus, long individual names were coded with shorter names (Supplementary File 1D). Using --keep, we kept individuals and populations used in our further analyses. Plink binary files were back-converted to EIGENSTRAT using convertf, setting outputgroup to YES, familyname to NO and hashcheck to NO. The resulting EIGENSTRAT ind file had population and individual names fused in column 1, sex in column 2 and individual number in column 3 (e.g. Mapuche:GS000011196-ASM F 13199). In order to keep proper population and individual names, we sorted the ind file, obtaining individual ID, sex and population ID in columns 1, 2 and 3, respectively (e.g. GS000011196-ASM F Mapuche). Finally, D-statistics were run using qpDstat implemented in ADMIXTOOLS. The population combinations for each test are shown in Supplementary File 1A-C. Results were considered significant if the Z-score $>|3|$. Even though some populations were sequenced with more than one technology [26, we show all results in Supplementary File 1.

\subsection{Admixture graph modeling}

We used qpGraph implemented in ADMIXTOOLS [27] with default settings except the following: useallsnps: YES, diag: 0.0001, lambdascale: 1. We evaluated model fit based on the model's score and the maximum $|Z|$-score, comparing predicted and observed values of the statistics. We explored two different models.

The first model explains the population splits and gene flow of MapucheHuilliche and the populations from Southern Cone region. We started with a suitable skeleton phylogenetic tree without admixture events and consisting of Mbuti, Anzick1, Argentina_ArroyoSeco2_7700BP, Chile_LosRieles_5100BP, Aymara and Chile_Conchali_700BP, reflecting the ideas of previous studies [6], 28], 8]. Then we successfully added a Southern Patagonia branch with Chile_WesternArchipelago_Ayayema_5100BP, Chile_WesternArchipelago_Kaweskar_1200BP without admixture events. Due to the affinity of Mapuche-Huilliche and Kaweskar, Mapuche and Yamana as well as observations from a previous study [8] we obtained the final result.

The second model represents the joint history of Mapuche-Huilliche and populations from the Central Andes region. We started with simple tree including 
Mbuti, Anzick1, Chile_Conchali_700BP, PE_LH_Inca. We added the remaining populations one-by-one consequently without admixture events paying attention on the score of the model and the value of the worst $f_{4}$-statistics.

\subsection{Ancestry-specific effective population size}

Before estimating Mapuche, European and African chromosomal segments among admixed Chileans, we used Admixture $1.3[63$ and $\mathrm{K}=4$ ancestral components to identify and exclude 592 individuals with $>1 \%$ global Aymara ancestry, obtaining a final dataset of 312 individuals. To estimate ancestry-specific $\mathrm{N}_{\mathrm{e}}$, we implemented the pipeline from Browning et al 2018 [30. We determined the gametic phase of each haplotype with Beagle v.5 62]. We used RFMix [33] to estimate the local ancestry of phased genotypes. The RFMix output data was then rephased to match the original phasing. We used Refined IBD [32] with default settings together with the merge-ibd-segments utility to assign IBD segments longer than $2 \mathrm{cM}$ to individual haplotypes. We used the filtercolumns.jar utility and the adjust_npairs.py python script to calculate the adjusted number of pairs of haplotypes. Finally, we run IBDNe (version ibdne.07May18.6a4.jar) 34 to estimate ancestry-specific effective population sizes.

\subsection{Simulations of local ancestry}

We performed simulations of local ancestry under a neutral scenario using the software SELAM [66], similarly as described in Vicunã et al., 2020 [37. Briefly, we modeled a single pulse of admixture between three populations occurring $g=10$ generations ago $(1 \mathrm{~g}=28$ years $[67])$. This time corresponds to the time where the main pulse of admixture occurred in admixed Chileans [36]. We set mean global ancestry proportions of 0.46 Native American, 0.52 European and 0.015 African, which are the same empirical proportions estimated for our Chilean population by RFMix. We set a constant effective population size $\left(\mathrm{N}_{\mathrm{e}}\right)$ $=6,000$ for admixed Chileans, based on previous estimates [37. We performed simulations using diploid (haploid) sample sizes of $\mathrm{N}=156$ (312), 312 (624), 624 (1248) and 904 (1808). We simulated 189 chromosomes, each of length 20 Morgans, in order to equate the empirical length of the human genome. We mapped the physical positions of our empirical SNPs on the simulated chromosomes. Afterwards, we calculated $T$-test $P$-values for the SNP with a maximal deviation in Native American ancestry. Variants achieving a threshold of $P$ $<10^{-5}$ were considered significant [35].

\subsection{Variant annotations}

Sequence Ontology (SO) consequence type were retrieved using the web tool VEP from Ensembl [68. 


\section{Funding}

L.V., S.E. and T.N. were supported by ANID FONDECYT Grants [11200324 to L.V.; 1200146 to S.E. and T.N.]. S.E., L.V. and T.N. were additionally supported by the Instituto Milenio de Investigación Sobre los Fundamentos de los Datos (IMFD). A.I., O.K., V.S. worked on this paper within the framework of the HSE University Basic Research Program. A.M. was supported by the grant RFBR 20-29-01028.

\section{Acknowledgements}

L.V. conceived the project, designed experiments and wrote the manuscript. L.V., A.M., T.N. and A.I. analyzed the data. O.K. performed simulations. L.V and V.S. supervised the work. S.E. provided data and funding. All authors critically reviewed and accepted the final version. L.V. thanks Felipe I. Martínez from Pontificia Universidad Católica de Chile for critically revising the manuscript. The authors declare that they have no competing financial interests.

\section{References}

[1] Ardelean CF, Becerra-Valdivia L, Pedersen MW, Schwenninger JL, Oviatt CG, Macías-Quintero JI, et al. Evidence of human occupation in Mexico around the Last Glacial Maximum. Nature. 2020 08;584(7819):87-92.

[2] Bennett MR, Bustos D, Pigati JS, Springer KB, Urban TM, Holliday VT, et al. Evidence of humans in North America during the Last Glacial Maximum. Science. 2021 09;373(6562):1528-31.

[3] Becerra-Valdivia L, Higham T. The timing and effect of the earliest human arrivals in North America. Nature. 2020 08;584(7819):93-7.

[4] Raghavan M, Steinrücken M, Harris K, Schiffels S, Rasmussen S, DeGiorgio $\mathrm{M}$, et al. Genomic evidence for the Pleistocene and recent population history of Native Americans. Science. 2015 Aug;349(6250):aab3884.

[5] Moreno-Mayar JV, Vinner L, de Barros Damgaard P, de la Fuente C, Chan J, Spence JP, et al. Early human dispersals within the Americas. Science. 2018 12;362(6419).

[6] Posth C, Nakatsuka N, Lazaridis I, Skoglund P, Mallick S, Lamnidis TC, et al. Reconstructing the Deep Population History of Central and South America. Cell. 2018 11;175(5):1185-97.e22.

[7] Dillehay TD, Ramírez C, Pino M, Collins MB, Rossen J, Pino-Navarro JD. Monte Verde: seaweed, food, medicine, and the peopling of South America. Science. 2008 May;320(5877):784-6. 
[8] Nakatsuka N, Luisi P, Motti JMB, Salemme M, Santiago F, D'Angelo Del Campo MD, et al. Ancient genomes in South Patagonia reveal population movements associated with technological shifts and geography. Nat Commun. 2020 Aug;11(1):3868.

[9] Ioannidis AG, Blanco-Portillo J, Sandoval K, Hagelberg E, Miquel-Poblete JF, Moreno-Mayar JV, et al. Native American gene flow into Polynesia predating Easter Island settlement. Nature. 2020 07;583(7817):572-7.

[10] Castro E Silva MA, Ferraz T, Bortolini MC, Comas D, Hünemeier T. Deep genetic affinity between coastal Pacific and Amazonian natives evidenced by Australasian ancestry. Proc Natl Acad Sci U S A. 2021 Apr;118(14).

[11] El Pueblo Mapuche. Los primeros estudios (1882-1940). Memoria Chilena. Biblioteca Nacional de Chile;. Available from: "http://www.memoriachi lena.gob.cl/602/w3-article-781.html"

[12] Encina FA. Historia de Chile. Tomo I, Capítulo III, Acápite 3. Editorial Nascimiento; 1954.

[13] Falabella F. Prehistoria en Chile. Desde sus primeros habitantes hasta los Incas. Capítulos VIII-IX. Santiago de Chile: Universitaria, 2016. Primera Edición;.

[14] Lachtam R. El origen de los Araucanos. En: La organización social y las creencias religiosas de los antiguos araucanos. Publicaciones del Museo ed Etnología y Antropología de Chile. Vol. III, pp. 254-268. Santiago de Chile (p. 23); 1924.

[15] Bengoa J. Historia del pueblo Mapuche: Siglo XIX y XX (Sexta Edición). Santiago de Chile. Editorial LOM.; 2000.

[16] Dillehay TD. Cultivated wetlands and emerging complexity in south-central Chile and long distance effects of climate change. Antiquity. 2007:949-60.

[17] de la Vega de Inca G. Comentarios reales Segunda Parte : Libro VII Cap $19-20 ; 1616$.

[18] Bengoa J. Historia de los antiguos Mapuches del sur. Santiago: Catalonia.; 2003.

[19] Ko A, Cantor RM, Weissglas-Volkov D, Nikkola E, Reddy PMVL, Sinsheimer JS, et al. Amerindian-specific regions under positive selection harbour new lipid variants in Latinos. Nat Commun. 2014;5:3983.

[20] Amorim CE, Nunes K, Meyer D, Comas D, Bortolini MC, Salzano FM, et al. Genetic signature of natural selection in first Americans. Proc Natl Acad Sci U S A. 2017 02;114(9):2195-9. 
[21] Lindo J, Huerta-Sánchez E, Nakagome S, Rasmussen M, Petzelt B, Mitchell J, et al. A time transect of exomes from a Native American population before and after European contact. Nat Commun. 2016 Nov;7:13175.

[22] Lindo J, Haas R, Hofman C, Apata M, Moraga M, Verdugo RA, et al. The genetic prehistory of the Andean highlands 7000 years BP though European contact. Sci Adv. 2018 Nov;4(11):eaau4921.

[23] Ávila Arcos MC, McManus KF, Sandoval K, Rodríguez-Rodríguez JE, Villa-Islas V, Martin AR, et al. Population History and Gene Divergence in Native Mexicans Inferred from 76 Human Exomes. Molecular Biology and Evolution. 2019 12;37(4):994-1006. Available from: https: //doi.org/10.1093/molbev/msz282

[24] Cheng JY, Stern AJ, Racimo F, Nielsen R. Detecting Selection in Multiple Populations by Modeling Ancestral Admixture Components. Molecular Biology and Evolution. 2021 10. Msab294. Available from: https://doi. org $/ 10.1093 / \mathrm{molbev} / \mathrm{msab} 294$.

[25] Ongaro L, Mondal M, Flores R, Marnetto D, Molinaro L, Alarcón-Riquelme $\mathrm{ME}$, et al. Continental-scale genomic analysis suggests shared postadmixture adaptation in the Americas. Human Molecular Genetics. 2021 07;30(22):2123-34. Available from: https://doi.org/10.1093/hmg/ddab 177.

[26] Allen Ancient DNA Resource;. Available from: "https://reich.hms.ha rvard.edu/allen-ancient-dna-resource-aadr-downloadable-genot ypes-present-day-and-ancient-dna-data".

[27] Patterson N, Moorjani P, Luo Y, Mallick S, Rohland N, Zhan Y, et al. Ancient admixture in human history. Genetics. 2012 Nov;192(3):1065-93.

[28] Nakatsuka N, Lazaridis I, Barbieri C, Skoglund P, Rohland N, Mallick S, et al. A Paleogenomic Reconstruction of the Deep Population History of the Andes. Cell. 2020 May;181(5):1131-45.e21.

[29] Pereira A, Garmendia ML, González D, Kain J, Mericq V, Uauy R, et al. Breast bud detection: a validation study in the Chilean growth obesity cohort study. BMC Womens Health. 2014;14:96.

[30] Browning SR, Browning BL, Daviglus ML, Durazo-Arvizu RA, Schneiderman N, Kaplan RC, et al. Ancestry-specific recent effective population size in the Americas. PLoS Genet. 2018 05;14(5):e1007385.

[31] Vicuña L, Norambuena T, Miranda JP, Pereira A, Mericq V, Ongaro L, et al. Novel loci and Mapuche genetic ancestry are associated with pubertal growth traits in Chilean boys. Hum Genet. 2021 May. 
[32] Browning BL, Browning SR. Improving the accuracy and efficiency of identity-by-descent detection in population data. Genetics. 2013 Jun;194(2):459-71.

[33] Maples BK, Gravel S, Kenny EE, Bustamante CD. RFMix: a discriminative modeling approach for rapid and robust local-ancestry inference. Am J Hum Genet. 2013 Aug;93(2):278-88.

[34] Browning SR, Browning BL. Accurate Non-parametric Estimation of Recent Effective Population Size from Segments of Identity by Descent. Am J Hum Genet. 2015 Sep;97(3):404-18.

[35] Bhatia G, Tandon A, Patterson N, Aldrich MC, Ambrosone CB, Amos C, et al. Genome-wide scan of 29,141 African Americans finds no evidence of directional selection since admixture. Am J Hum Genet. 2014 Oct;95(4):437-44.

[36] Eyheramendy S, Martinez FI, Manevy F, Vial C, Repetto GM. Genetic structure characterization of Chileans reflects historical immigration patterns. Nat Commun. 2015;6:6472.

[37] Vicuña L, Klimenkova O, Norambuena T, Martinez FI, Fernandez MI, Shchur V, et al. Postadmixture Selection on Chileans Targets Haplotype Involved in Pigmentation, Thermogenesis and Immune Defense against Pathogens. Genome Biol Evol. 2020 08;12(8):1459-70.

[38] Stehberg R SG. Mapocho Incaico. Boletín del Museo Nacional de Historia Natural, Chile. 61: 85-149; 2012.

[39] Menghin O. Estudios de Prehistoria Araucana. Acta Prehistórica III-IV; 1959-1960.

[40] Vidal EA, Moyano TC, Bustos BI, Pérez-Palma E, Moraga C, Riveras E, et al. Whole Genome Sequence, Variant Discovery and Annotation in Mapuche-Huilliche Native South Americans. Sci Rep. 2019 02;9(1):2132.

[41] Quevedo S DE. Ofrendas a los dioses en las montañas: Santuarios de altura de la cultura inka. Bol. Mus. Nac. Hist. Nat. 43:193-206; 1992.

[42] Marsh E, Roddick A, Bruno M, Smith S, Janusek J, Hastorf C. Temporal Inflection Points in Decorated Pottery: A Bayesian Refinement of the Late Formative Chronology in the Southern Lake Titicaca Basin, Bolivia. Latin American Antiquity. 2019;30(4):798-817.

[43] Bullock D. Urnas funerarias prehistóricas de la Región de Angol. Boletín del Museo Nacional de Historia Natural, XXVI(5):73-157.; 1955.

[44] Bullock D. La Cultura Kofkeche. Imprenta Alianza. Angol.; 1955. 
[45] Castro E Silva MA, Nunes K, Lemes RB, Mas-Sandoval À, Guerra Amorim CE, Krieger JE, et al. Genomic insight into the origins and dispersal of the Brazilian coastal natives. Proc Natl Acad Sci U S A. 2020 02;117(5):2372-7.

[46] Silva Galdames O. ¿ Detuvo la Batalla del Maule la expansión Inca hacia el Sur de Chile? Cuadernos de Historia. 3: 7-25; 1983.

[47] Sinnott-Armstrong N, Tanigawa Y, Amar D, Mars N, Benner C, Aguirre $\mathrm{M}$, et al. Genetics of 35 blood and urine biomarkers in the UK Biobank. Nat Genet. 2021 02;53(2):185-94.

[48] Richardson TG, Sanderson E, Palmer TM, Ala-Korpela M, Ference BA, Davey Smith G, et al. Evaluating the relationship between circulating lipoprotein lipids and apolipoproteins with risk of coronary heart disease: A multivariable Mendelian randomisation analysis. PLoS Med. 2020 03;17(3):e1003062.

[49] Chen MH, Raffield LM, Mousas A, Sakaue S, Huffman JE, Moscati A, et al. Trans-ethnic and Ancestry-Specific Blood-Cell Genetics in 746,667 Individuals from 5 Global Populations. Cell. 2020 09;182(5):1198-213.e14.

[50] NEEL JV. Diabetes mellitus: a "thrifty" genotype rendered detrimental by "progress"? Am J Hum Genet. 1962 Dec;14:353-62.

[51] Miquel J. Salud y enfermedad en nuestras poblaciones originarias. Rev Chil Cardiol. 2012;31:129-33.

[52] Burrows R, Correa-Burrows P, Reyes M, Blanco E, Albala C, Gahagan S. High cardiometabolic risk in healthy Chilean adolescents: associations with anthropometric, biological and lifestyle factors. Public Health Nutr. 2016 Feb;19(3):486-93.

[53] Rasmussen M, Anzick SL, Waters MR, Skoglund P, DeGiorgio M, Stafford TW Jr, et al. The genome of a Late Pleistocene human from a Clovis burial site in western Montana. Nature. 2014 Feb;506(7487):225-9.

[54] Malaspinas AS, Lao O, Schroeder H, Rasmussen M, Raghavan M, Moltke I, et al. Two ancient human genomes reveal Polynesian ancestry among the indigenous Botocudos of Brazil. Curr Biol. 2014 Nov;24(21):R1035-7.

[55] Skoglund P, Mallick S, Bortolini MC, Chennagiri N, Hünemeier T, PetzlErler ML, et al. Genetic evidence for two founding populations of the Americas. Nature. 2015 Sep;525(7567):104-8.

[56] Mallick S, Li H, Lipson M, Mathieson I, Gymrek M, Racimo F, et al. The Simons Genome Diversity Project: 300 genomes from 142 diverse populations. Nature. 2016 Oct;538(7624):201-6. 
[57] de la Fuente C, Ávila-Arcos MC, Galimany J, Carpenter ML, Homburger JR, Blanco A, et al. Genomic insights into the origin and diversification of late maritime hunter-gatherers from the Chilean Patagonia. Proc Natl Acad Sci U S A. 2018 04;115(17):E4006-12.

[58] Bongers JL, Nakatsuka N, O’Shea C, Harper TK, Tantaleán H, Stanish $\mathrm{C}$, et al. Integration of ancient DNA with transdisciplinary dataset finds strong support for Inca resettlement in the south Peruvian coast. Proc Natl Acad Sci U S A. 2020 Aug;117(31):18359-68.

[59] Bergström A, McCarthy SA, Hui R, Almarri MA, Ayub Q, Danecek P, et al. Insights into human genetic variation and population history from 929 diverse genomes. Science. 2020 03;367(6484).

[60] 1000 Genomes Project Consortium, Auton A, Brooks LD, Durbin RM, Garrison EP, Kang HM, et al. A global reference for human genetic variation. Nature. 2015 Oct;526(7571):68-74.

[61] Chacón-Duque JC, Adhikari K, Fuentes-Guajardo M, Mendoza-Revilla J, Acuña-Alonzo V, Barquera R, et al. Latin Americans show wide-spread Converso ancestry and imprint of local Native ancestry on physical appearance. Nat Commun. 2018 12;9(1):5388.

[62] Browning SR, Browning BL. Rapid and accurate haplotype phasing and missing-data inference for whole-genome association studies by use of localized haplotype clustering. Am J Hum Genet. 2007 Nov;81(5):1084-97.

[63] Alexander DH, Novembre J, Lange K. Fast model-based estimation of ancestry in unrelated individuals. Genome Res. 2009 Sep;19(9):1655-64.

[64] Crawford JE, Amaru R, Song J, Julian CG, Racimo F, Cheng JY, et al. Natural Selection on Genes Related to Cardiovascular Health in HighAltitude Adapted Andeans. Am J Hum Genet. 2017 Nov;101(5):752-67.

[65] Manichaikul A, Mychaleckyj JC, Rich SS, Daly K, Sale M, Chen WM. Robust relationship inference in genome-wide association studies. Bioinformatics. 2010 Nov;26(22):2867-73.

[66] Corbett-Detig R, Jones M. SELAM: simulation of epistasis and local adaptation during admixture with mate choice. Bioinformatics. 2016 10;32(19):3035-7.

[67] Wang CC, Reinhold S, Kalmykov A, Wissgott A, Brandt G, Jeong C, et al. Ancient human genome-wide data from a 3000-year interval in the Caucasus corresponds with eco-geographic regions. Nature Communications. 2019 Feb;10(1):590.

[68] McLaren W, Gil L, Hunt SE, Riat HS, Ritchie GRS, Thormann A, et al. The Ensembl Variant Effect Predictor. Genome Biol. 2016;17(1):122. 
bioRxiv preprint doi: https://doi.org/10.1101/2021.11.25.470066; this version posted November 29, 2021. The copyright holder for this preprint (which was not certified by peer review) is the author/funder, who has granted bioRxiv a license to display the preprint in perpetuity. It is made available under aCC-BY-ND 4.0 International license.

\begin{tabular}{|c|c|c|}
\hline SNP & Consequence & Gene \\
\hline rs117708622 & intron & CPNE2 \\
\hline rs116542428 & intron & CPNE2 \\
\hline rs62037310 & intron & CPNE2 \\
\hline rs74854155 & intron & CPNE2 \\
\hline rs78828067 & intron & CPNE2 \\
\hline rs4784770 & intron & CPNE2 \\
\hline rs4783976 & intron & CPNE2 \\
\hline rs4784771 & intron & CPNE2 \\
\hline rs148676407 & intron & CPNE2 \\
\hline rs117726982 & intron & CPNE2 \\
\hline rs75320780 & intron & CPNE2 \\
\hline rs534235590 & intron & CPNE2 \\
\hline rs9921622 & intron & CPNE2 \\
\hline rs71387152 & intron & CPNE2 \\
\hline rs149722836 & intron & CPNE2 \\
\hline rs150251022 & intron & CPNE2 \\
\hline rs147408120 & intron & CPNE2 \\
\hline rs186013874 & missense & CPNE2 \\
\hline rs552065125 & missense/splicing & CPNE2 \\
\hline rs185279527 & intron & CPNE2 \\
\hline rs113552373 & intron & CPNE2 \\
\hline rs17372662 & downstream & CPNE2 \\
\hline rs62037353 & downstream & CPNE2 \\
\hline rs17372800 & downstream & CPNE2 \\
\hline rs74544530 & synonymous & FAM192A \\
\hline rs55680142 & intron & FAM192A \\
\hline rs73551501 & intron & FAM192A \\
\hline rs80135280 & intron & FAM192A \\
\hline rs3764259 & intron & FAM192A \\
\hline rs77056538 & 5' UTR & RSPRY1 \\
\hline rs77353290 & intron & RSPRY1 \\
\hline rs7197204 & intron & $R S P R Y 1$ \\
\hline rs141968924 & intron & $R S P R Y 1$ \\
\hline
\end{tabular}

\begin{tabular}{|c|c|c|}
\hline SNP & Consequence & Gene \\
\hline rs6499871 & intron & $R S P R Y 1$ \\
\hline rs114347995 & intron & $R S P R Y 1$ \\
\hline rs375513384 & missense & RSPRY1 \\
\hline rs146595587 & intron & RSPRY1 \\
\hline rs112718122 & intron & RSPRY 1 \\
\hline rs58714624 & missense & $R S P R Y 1$ \\
\hline rs2288006 & intron & $R S P R Y 1$ \\
\hline rs16967938 & intron & RSPRY1 \\
\hline rs149620070 & intron & RSPRY1 \\
\hline rs556681022 & intron & $A R L 2 B P$ \\
\hline rs9843 & 3' UTR & $A R L 2 B P$ \\
\hline rs35274397 & missense & PLLP \\
\hline rs151154545 & missense & PLLP \\
\hline rs201731371 & missense & PLLP \\
\hline rs35467222 & missense & PLLP \\
\hline rs75910213 & intron & PLLP \\
\hline rs58327961 & intron & PLLP \\
\hline rs11642528 & intron & PLLP \\
\hline rs72778735 & intron & PLLP \\
\hline rs73553060 & intron & PLLP \\
\hline rs11640439 & intron & PLLP \\
\hline rs79327369 & intron & PLLP \\
\hline rs11644697 & intron & PLLP \\
\hline rs541742745 & intron & PLLP \\
\hline rs113410670 & intron & PLLP \\
\hline rs4293366 & intron & PLLP \\
\hline rs76920892 & intron & PLLP \\
\hline rs11861212 & intron & PLLP \\
\hline rs9922349 & intron & PLLP \\
\hline rs59469976 & intron & PLLP \\
\hline rs78574962 & intron & PLLP \\
\hline rs75879074 & intron & PLLP \\
\hline
\end{tabular}

Supplementary Table 1. Variants undergoing Mapuche-specific post-admixture selection in admixed Chileans. Shown are the SNP ID, SO consequence type and associated gene. 